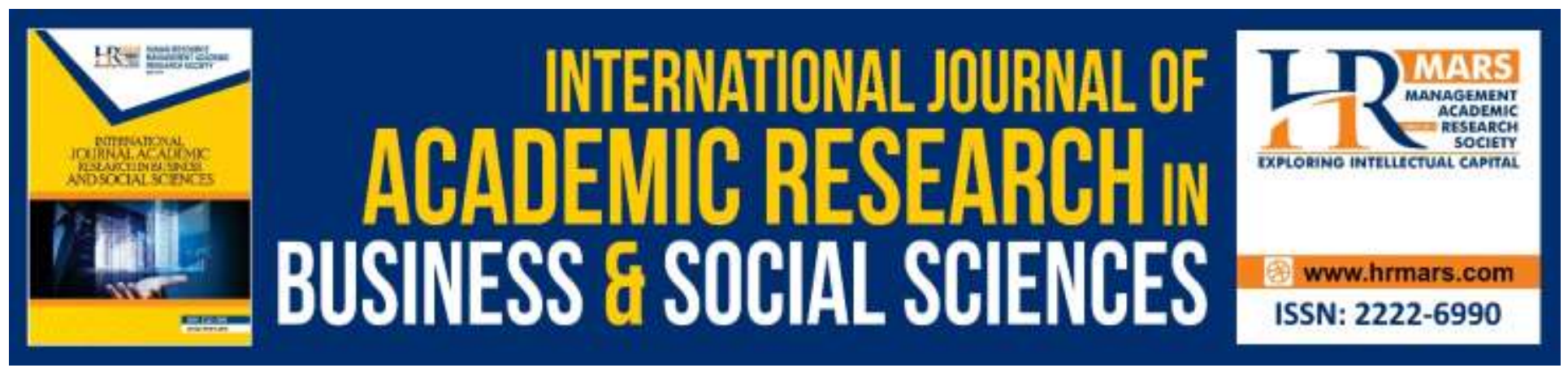

\title{
Factors Influencing Labour Productivity in Oil Palm Estate
}

Farahida Zulkefli, Syahrizan Syahlan, Muhammad Aliuddin Bakar, Mohd Fairuz Khalid and Ismail Rakibe

To Link this Article: http://dx.doi.org/10.6007/IJARBSS/v10-i4/7114 DOI:10.6007/IJARBSS/v10-i4/7114

Received: 09 February 2020, Revised: 09 March 2020, Accepted: 28 March 2020

Published Online: 12 April 2020

In-Text Citation: (Zulkefli et al., 2020)

To Cite this Article: Zulkefli, F., Syahlan, S., Bakar, M. A., Khalid, M. F., \& Rakibe, I. (2020). Factors Influencing Labour Productivity in Oil Palm Estate. International Journal of Academic Research in Business and Social Sciences, 10(4), 119-131.

Copyright: (C) 2020 The Author(s)

Published by Human Resource Management Academic Research Society (www.hrmars.com)

This article is published under the Creative Commons Attribution (CC BY 4.0) license. Anyone may reproduce, distribute, translate and create derivative works of this article (for both commercial and non-commercial purposes), subject to full attribution to the original publication and authors. The full terms of this license may be seen

at: http://creativecommons.org/licences/by/4.0/legalcode

Vol. 10, No. 4, 2020, Pg. 119 - 131

http://hrmars.com/index.php/pages/detail/IJARBSS

JOURNAL HOMEPAGE

Full Terms \& Conditions of access and use can be found at http://hrmars.com/index.php/pages/detail/publication-ethics 


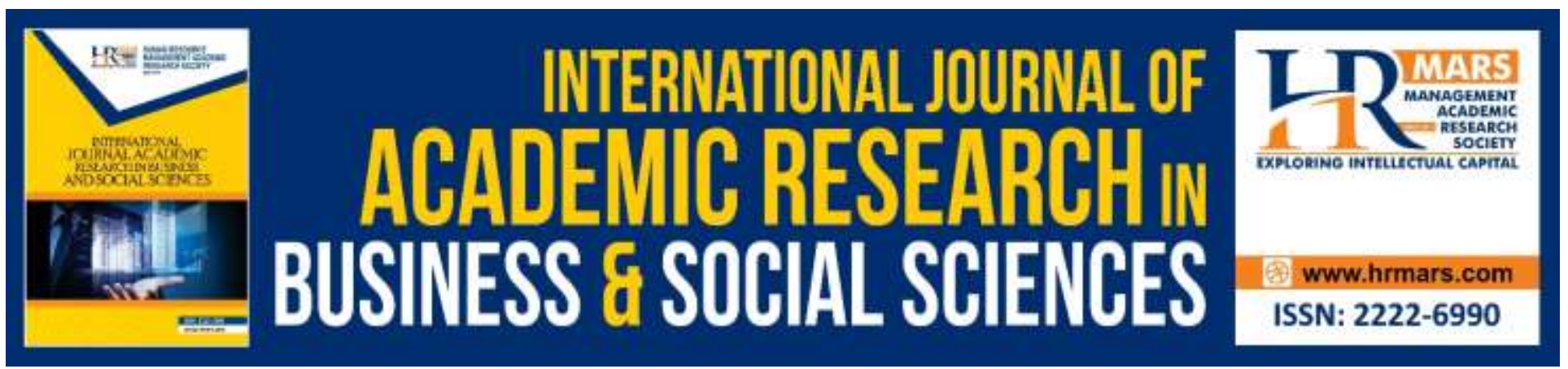

\title{
Factors Influencing Labour Productivity in Oil Palm Estate
}

\author{
Farahida Zulkefli, Syahrizan Syahlan, Muhammad Aliuddin Bakar, \\ Mohd Fairuz Khalid and Ismail Rakibe \\ Faculty of Plantation and Agrotechnology, Universiti Teknologi MARA (UiTM), Jasin 77300, Melaka \\ Malaysia \\ Email: syahrizan@rocketmail.com
}

\begin{abstract}
Literally, there are few be studies that look at the agricultural employees' productivity, especially in oil palm sector. Therefore, this survey aims to study on factors influencing labour productivity at Selandar Jasin Melaka. In this case study, the elements are wages, benefit, positives climate and appreciation. A close ended questionnaire was used as a tool to collect data. The respondents were selected using a stratified sampling technique. From 120 people as population, 97 were responded, based on job title given by the oil palm company. The analytical method used are descriptive, correlation and regression analysis. The results of this study indicate that there is a positive relationship and significant influence simultaneously between all the factors $(r=.829, .775, .721$, .564 ) on labour productivity. Wages ( $B: 0.393)$ is the variable of the most powerful influence on labour productivity, so it needs special attention. The study also found that a significant number of employees are not very happy and feel safely about their working climate. Furthermore, it is also imperative for managers to understand that wages and benefit have a fundamental role to play in enhancing labour productivity. However, these factors have been revaluated in time, and labour productivity determinants information is still inadequate.
\end{abstract}

Keywords: Employee Productivity, Appreciation, Positive Climate, Wages and Benefit.

\section{Introduction}

Malaysia's labour productivity rose in the first quarter of 2019 compared to the previous year according to figures from the Department of Statistics Malaysia. Malaysia measures its labour productivity in two different ways. The first is measured by value added per hour worked. In Q1 this value rose $2.4 \%$ when compared to the previous year. The second way is expressed as the ratio of value added to employment. Labour productivity by hours worked for Agriculture sector rebounded to 3.0 per cent from a negative growth of 0.7 per cent in the previous quarter. The growth was mainly supported by the better performance of Crops \& Livestock and Forestry \& Logging. The value added 
INTERNATIONAL JOURNAL OF ACADEMIC RESEARCH IN BUSINESS AND SOCIAL SCIENCES Vol. 10, No. 4, April, 2020, E-ISSN: 2222-6990 @ 2020 HRMARS

of this sector turned around markedly to rise by 5.6 per cent (Q4 2018: -0.1\%) while hours worked expanded 2.5 per cent (Q4 2018: 0.6\%). Meanwhile, labour productivity by employment grew 3.4 per cent against negative 0.3 per cent in the preceding quarter as employment grew 2.2 per cent (Q4 2018: 0.2\%). However, in oil palm sector, the yield already stagnant for almost 20 years; below than 20 metric tons per hectare. It is more upset when the settlers only managed to get below than 10 metric tons per hectare (MPOB, 2018). Even though the labour shortage in the plantation sector has now come down sharply to about 15,000 workers from 50,000 (MPOB, 2019). Malaysia is struggling to attract new expatriate workers and retain those already active in the sector. Even the local youth also have a negative perception working in oil palm estate. Oil palm plantation companies must counter this for the workers to give out more for the sake of their employer. Given the demanding nature of the job, the inhospitable living conditions and low wages, plantation companies find it difficult to recruit labour. Majority about 85 per cent of workers in oil palm plantations in Malaysia are from Indonesia, Bangladesh, Nepal, Cambodia and India. In some plantations, there are also Rohingya workers. The purpose of this paper is to highlight some areas where plantation companies could make improvements in their continuing quest to make work on plantations more humane, rewarding and welcoming. Working atmosphere at the plantations are hard and the living environment is uninviting. It is not surprising that Malaysians are generally not prepared to work on the plantations. Raising labour productivity, therefore, seems to be the only way to solve the problem of a tight labour market because the supply is not able to fulfill the demand for labour in the oil palm plantation sector. In the oil palm industry, and especially in the plantation sector, monitoring labour productivity is most crucial in ensuring that the industry remains competitive in the global market and continues to be among the main contributors to GNI.

The main objectives of this study are:

1. To study on factors influencing labour productivity at Selandar Jasin Melaka.

2. To determine the most influencing variable in affecting the labour productivity.

Until today, there are not many studies that look at the factors that influencing oil palm labours productivity. Most of the previous studies particularly in the field of plantation sector in Malaysia highlight the comparison between harvester and CKAT productivity (Aliuddin et al., 2018), Buffalo Assistance for In-Field Collection Of Fresh Fruit Bunches In Oil Palm Buffalo Assistance for In-Field Collection Of Fresh Fruit Bunches In Oil Palm Plantation (Syahrizan et al., 2017) and An Overview of Acceptance and Adoption of Agricultural Innovation and Technology for Sustainable Palm Oil Industry (Farahida et al., 2017). To understand the labor force issue in palm oil plantation sector that relates with the worker's welfare, the research questions (RQ) for this paper is: What are the components that affecting the level of the causes? Thus, this study provides a better understanding of the factors that contribute to productivity among workers in oil palm estate. Result from this study also could shed in light some guideline to help management in Plantations companies to develop a strategy increase the level of employee productivity toward their job. This survey is to convince the organization that Human Resource Management (HRM) is vitally important to enhance their employee engagement. With the result, discussion and conclusion, it is hope that employees will be getting the higher level of security, increase their performance and feel happy to work in the plantation sector. The paper begins with a tour of the literature regarding the structure of labour and the role of the oil palm company; this section concludes with a statement of the study's hypotheses. 
INTERNATIONAL JOURNAL OF ACADEMIC RESEARCH IN BUSINESS AND SOCIAL SCIENCES

Vol. 10, No. 4, April, 2020, E-ISSN: 2222-6990 @ 2020 HRMARS

The study methodology then follows. Subsequently, the survey results are analyzed. A discussion of these results concludes the study.

\section{Review of Literature}

In the following section, this paper presents the literature describing the hypothesized relationships among various variables of this study

\section{Labour Productivity}

In administrative aspect, the term labour productivity is based on the concepts of efficiency and effectiveness of labour in achieving optimal use of available resources, and the administration's ability to convert the input to the output of the Organization specifications required and at the lowest possible cost (Al Hawari, 2008). While oil palm is the higher-yielding crop than other vegetable oils, Malaysia and Indonesia are being left behind in terms of productivity improvements. Over the past 20 years, the Malaysian palm oil industry had improved its production yield by $5 \%$, but this was a far cry from the US soybean oil and European rapeseed oil, whose yields had grown by $50 \%$ and $45 \%$ respectively during that period. Measured labour productivity will vary as a function of other input factors as well as the efficiency with which the factors of production are used (total factor productivity). So, two firms or countries may have the same total factor productivity (productive technologies) but because one has more capital to use, its labour productivity will be higher. Output per worker corresponds to the 'average product of labour' and can be contrasted with the marginal product of labour, which refers to the increase in output which results from a corresponding (marginal) increase in labour input. On top of that, industry player pointed out that the usual harvesting interval or cycle of 20 days had now been extend to 30 days in many Malaysian plantations due to this acute labour shortage. On average, one worker in the plantations (at the field level) in Malaysia produced 174 mt FFB per year. On a regional basis, labour in Peninsular Malaysia was more productive as compared with the other regions. One worker in Peninsular Malaysia produced about 199 mt FFB per year compared with 161 and 156 mt per year in Sarawak and Sabah, respectively A FFB harvester and collector in Peninsular Malaysia produced a total of $437 \mathrm{mt}$ FFB per year, higher than in the other regions (MPOB, 2018).

\section{Wages}

Many empirical works have been conducted to examine the relationship between real wages and labour productivity in the developed and developing economies. They found that real wages and labour productivity are closely connected, but the direction of causality for these variables remains ambiguous. Two theories have rooted the causal relationship between real wages and labour productivity. First, the marginal productivity theory postulated that employers usually practice the performance-based wages and profit optimization strategy. They will recruit labour up to a level where the marginal productivity of labour equal to the marginal cost that is labour wages. As supported by Ting (1997), his study declares the significant of pay that it is strong determinant of job satisfaction. Moreover, he explains two different type of pay practices effect on job satisfaction; satisfaction with pay itself and satisfaction with financial prospects in the upcoming. There is a longstanding interest of two items which are correlated with job satisfaction. 
INTERNATIONAL JOURNAL OF ACADEMIC RESEARCH IN BUSINESS AND SOCIAL SCIENCES

Vol. 10, No. 4, April, 2020, E-ISSN: 2222-6990 @ 2020 HRMARS

\section{Benefit}

Although pay, benefits and organizational culture tend to be key indicators of job satisfaction, little attention is given to specific types of benefits, Audry Tillman (2013) advised that one way to mitigate employee turnover was for an organization to offer robust benefits. According to him, those who work for organizations that offer benefits with which employees are extremely satisfied or very satisfied are six times more likely to stay with their current employers than those who are dissatisfied with benefits. Boushey and Glynn (2012) found that some policies can help to reduce employee turnover, including family-friendly policies that give workers the flexibility to balance work and family. Meanwhile survey in academic institution showed, employees in faculty, staff or administrators, they tend to be satisfied if they feel their pay reflects their market value and if they have the respect of their co-worker (Bozeman and Gaughan, 2011). As the labor force participation of women and the fraction of dual-earner households in Western countries have increased dramatically in recent years, employers have responded by providing employment benefits, ranging from flexible scheduling to daycare to parental leave, which support a balance between work and family life, the researcher do not find evidence the majority of family supportive benefits increase productivity (Shuja et al, 2017). The exception is that employers offering flexible sick leave and childcare assistance have significantly lower turnover rates.

\section{Positive Climate}

Maimunah (2018) stated that productivity techniques will only flourish in organization which has a positive climate. Working conditions, such as salary and overall environment are important indicators of employment satisfaction and engagement (Hermsen and Rosser, 2008). The International Labour Office (2014), indicates low productivity of workers in the medium and small enterprises in developing countries, Because of poor physical working conditions in the workplace and occupational safety and health facilities. The study of Hameed and Amjad (2009) concluded to strong correlation between workplace design and productivity, and that $58 \%$ of the variation in employee productivity due to the design of the work environment. Results of the study Hoskins (2006) indicates that $90 \%$ of the senior officials noted that the design of the workplace is important to them and affect their productivity and expected to increase in the employee's performance up to $22 \%$, if their offices are designed well.

\section{Appreciation (Reward)}

Every organization especially University of Calabar Teaching Hospital (UCTH) needs a strategic reward system for employees (Schaufeli WB et al, 2002). Rewards play an important role in organizations (Bartol and Srivastava, 2002). Merit pay is more likely to be considered as a reward programmes (O'Reilly and Chatman, 1986). Also, merit pay is the allocation of pay raises based on individual performance, and one of the most prevalent compensation practices used by most employers in private sector, state government and local governments (Harmon, 2007). Performance bonus is a monetary reward that is given by employer to employees based on their performance appraisal and organization's profit (LaBelle, 2005). A bonus scheme is not an easy task to accomplish successfully in the organizations (Teddie and Tashakkori, 2007). A successful bonus scheme depends on performance of organization and focus on efficiency of goal setting process. Monetary rewards that is preferred by employees especially in the lower level category, is money in a form of bonus, trips 
INTERNATIONAL JOURNAL OF ACADEMIC RESEARCH IN BUSINESS AND SOCIAL SCIENCES Vol. 10, No. 4, April, 2020, E-ISSN: 2222-6990 @ 2020 HRMARS

paid for by the organization, gifts from a rewards catalog, or services such as cell phone or paid cable (Dada, 2004). The recognition of employee successes is a powerful tool in improving employee performance, morale, motivation, and employee productivity (Ahmad et al, 2010). Recognition is an important feeling that a person is made to feel special and this type of recognition must come from those employees, hold in high esteem and position, such as manager (Cho et al, 2006). Challenging work means an increase in the scope of work to the highest level of individual's capability so that employees become more energetic in handling and performing their job (Wong et al, 1999). Let employee have a freedom to make mistake and from this mistake they will learn something new and become better persons. This will improve their performance (Schaufeli WB et al, 2002). Monetary rewards are financial inducement that positively leads to high productivity in the organization.

\section{Materials and Methods}

Based on prior studies the following theoretical model has been developed to illustrate the impact of wages, benefit, positive climate and appreciation on employee productivity (Figure 1)

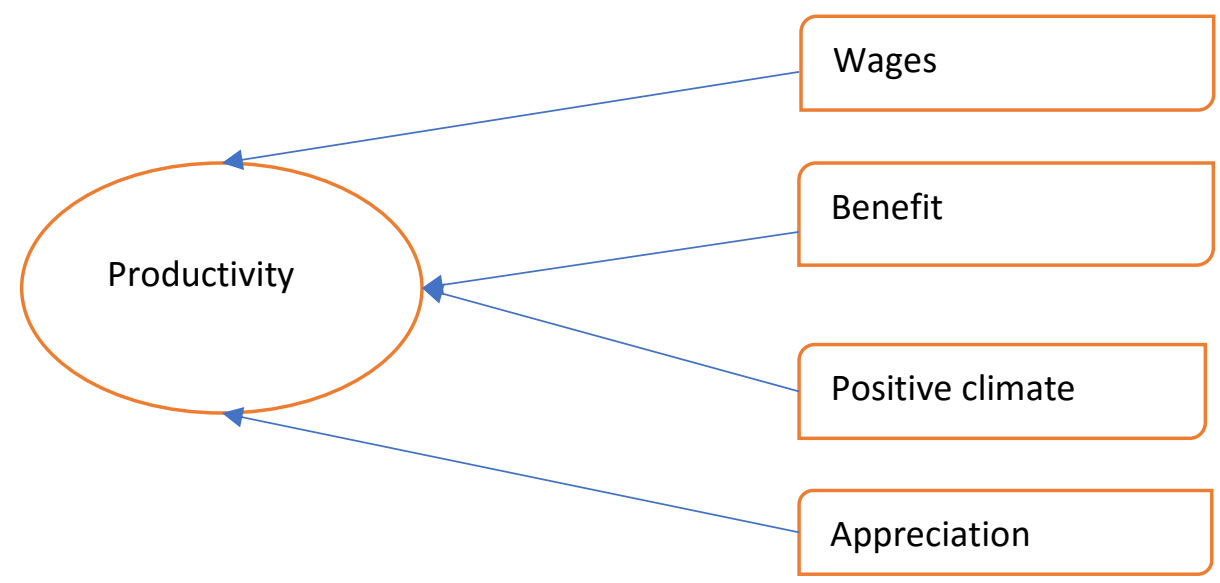

Figure 1: Employee productivity

\section{Sample and procedure}

For this study the employees at the Selandar Jasin of Oil Palm Estate Melaka were questioned. In all, the target population numbered 120 individuals. Of this number, 92 respondents were sampled using Krejcie and Morgan (1970) formula for sample size determination. Ultimately, 97 questionnaires (97 per cent) were collected from respondents from the total of 100 given out. During data collection, the researcher distributes the questionnaire and gathers the data by face to face with the employees. By using this technique, the researcher has several advantages such as the researcher need a short period of time to collect the data as well as the researcher also can clarify the respondent problem about the questionnaire distributed on the spot. The researcher also may have advantages to elaborate more about the case study topics and make the respondent well understand before them answering the questionnaire. In order to ascertain the sample size from the different types of works (harvesting, fertilizer, spraying, maintenance, and mandor), this study adopted stratified random sampling. The primary objective was to ensure a fair representation of employees was drawn from 
each types of work. This was made more easily attainable by using a sampling frame containing the names of the employees in each nature of work. Having this frame in place, the researchers relied on the lottery method of simple random sampling to select the respondents from each stratum (type) of the frame. Simple random sampling was used with the intent of giving every employee an equal chance of being selected. However, critical and ardent consideration was attached to ethics such as privacy, confidentiality and voluntary participation. Table I presents the biographical profile (including gender, age groups, total length of service, citizenship, educational status, type of workers, salary total hours work per day) of the respondents.

\section{Results and Discussion}

Reliability Test

Internal consistency estimates were formulated using Cronbach's alpha coefficients. From table 1, the results of Cronbach's alpha show a positive consistency on the data if Cronbach's Alpha values ranging from 0.70 to 0.80 (Andy Field, 2017). This shows that the study based on the questionnaire is fit for this study. A maximum alpha value of 0.90 has been recommended (Green et al, 1977). It is suggested the alpha is too high that some items are redundant as they are testing the same question but in a different guise.

Table 1: Reliability Test

\begin{tabular}{lcr}
\hline Variables & Cronbach's Alpha & Status \\
\hline Wages & 0.799 & Reliable \\
Benefit & 0.842 & Reliable \\
Positive climate & 0.722 & Reliable \\
Appreciation & 0.758 & Reliable
\end{tabular}

Descriptive Analysis

The biographical information of the respondents is presented in table 2. Table 2 reveals the result of the biographical information of the respondents. The highest number of age among the respondent in the sample come from age 21 to 25 years old (34\%), followed by age between 26 to 30 years old (25.8\%). The lowest percentages in the sample is age between 36 to 40 years old (5.7\%). Employees gender shows that the male gender was the majority with $90.7 \%$ ( 88 respondents), on the other hand, only $9.3 \%$ (9 respondents) was female workers. In term of nationality, approximately $27.8 \%$ (27 respondents) of the respondents are local, and the rest $72.2 \%$ being heavily depend on migrant $(60 \%$ from Indonesia and $10.3 \%$ from Bangladesh). Further profiling of the respondents showed that 46 (46.4\%) respondents of this survey possessed less than 2 years working experience, meanwhile 29 (29\%) respondents has working experience between six to eight years. Respondents accounted have average between three years to five years working experience are 23 (23.7\%) respondents. Most of the respondents attained Diploma certificate which is $67(69.1 \%)$ respondents, followed by secondary school which is $21(21.6 \%)$ respondents and primary school have accounted $9(9.3 \%)$ respondents. With regard the job title occupied in the estate, the largest group of respondents are harvesters with 53 respondents (53.3\%), followed by maintenance workers 15 (15.5\%) respondents, with mandor (8.2\%) being the smallest number. 
INTERNATIONAL JOURNAL OF ACADEMIC RESEARCH IN BUSINESS AND SOCIAL SCIENCES

Vol. 10, No. 4, April, 2020, E-ISSN: 2222-6990 @ 2020 HRMARS

Table 2: Biographical information of respondents

\begin{tabular}{lllr}
\hline Demographic variables & Response categories & Frequency & \% \\
\hline Gender & Male & 88 & 90.7 \\
Age & Female & 9 & 9.3 \\
& $<20$ & 1 & 1.0 \\
& $21-25$ & 33 & 34.0 \\
& $26-30$ & 25 & 25.8 \\
& $31-35$ & 13 & 13.4 \\
Year of service in the current & $36-40$ & 5 & 5.2 \\
organization & Above 41 & 20 & 20.6 \\
& & & \\
Nationality & Less than 2 year & 45 & 46.4 \\
& $3-5$ years & 23 & 23.7 \\
Educational level & 6 - 8 years & 29 & 29.9 \\
& Malaysia & 27 & 27.8 \\
Job title & Indonesia & 60 & 61.9 \\
& Bangladesh & 10 & 10.3 \\
& Primary school & 9 & 9.3 \\
& Secondary school & 21 & 21.6 \\
& University & 67 & 69.1 \\
Wages & Harvester & 52 & 53.6 \\
& Fertilizer workers & 12 & 12.4 \\
Total works per day (hour) & Sprayer & 10 & 10.3 \\
& Maintenance workers & 15 & 15.5 \\
& Mandor & 8 & 8.2 \\
& 1050 & 17 & 17.5 \\
& $1060-2500$ & 68 & 70.1 \\
& More than2500 & 12 & 12.4 \\
& 8 & 79 & 81.4 \\
& More than 11 & 18 & 18.6
\end{tabular}

Relationship between Factors Contributed to Employee Productivity

Pearson Correlation Analysis was used to identify the relationship between the independent variables (wages, benefit, positive climate and appreciation) that affect the dependent variable (employee productivity). Theoretically, the higher value of the correlation between two variables, the more related these variables are to each other (these values show the strength of relationships among variables). The direction of relationships among variables is another issue that should be considered in analysing the correlations between variables. A positive correlation indicates that the direction of the relationship is positive (if one increases, the other one increases). Bivariate Correlations are used to know the nature, direction and significance of the bivariate relationship of the variables of this study. Therefore, the Bivariate Correlations procedures have used to compute Pearson's correlation coefficient. A rule of thumb is that multicollinearity may be a problem if a correlation is $>.90$, in the 
INTERNATIONAL JOURNAL OF ACADEMIC RESEARCH IN BUSINESS AND SOCIAL SCIENCES

Vol. 10, No. 4, April, 2020, E-ISSN: 2222-6990 @ 2020 HRMARS

correlation matrix formed by all the independent variables (Coakes S. J. and L. G. Steed, 2000). The correlation value is as presented in Table 2 below: -

Table 3: Correlation value Interpreted according to Hinkle, Wiersma and Jurs (2003)

\begin{tabular}{cc} 
Correlation Value & Relationship Strength \\
\hline .90 to 1.00 & Very high positive correlation \\
.70 to .90 & High positive correlation \\
.50 to .70 & Moderate positive correlation \\
.30 to .50 & Low positive correlation \\
.00 to .30 & Little if any correlation \\
0 & No relationship
\end{tabular}

Table 3: Analysis of a Correlation between wages, benefit, positive climate, appreciation and employee productivity.

\begin{tabular}{lccc}
\hline \multicolumn{3}{c}{ Absenteeism } \\
\hline Factors & $\begin{array}{c}\text { Significant } \\
(\boldsymbol{p})\end{array}$ & $\begin{array}{c}\text { Correlation } \\
\text { value } \\
(\boldsymbol{r})\end{array}$ & Relationship strength \\
\hline Wages & 0.004 & $0.829^{* *}$ & High positive correlation \\
Benefit & 0.007 & $0.775^{* *}$ & High positive correlation \\
Positive climate & 0.003 & $0.721^{* *}$ & High positive correlation \\
Appreciation & 0.000 & $0.564^{* *}$ & $\begin{array}{c}\text { Moderate positive } \\
\text { correlation }\end{array}$ \\
Notes: Survey Data $-2014 .{ }^{* *}$ Correlation is significant at the 0.01 (two-tailed)
\end{tabular}

The results of correlation analysis in table 3 reveals that there is positive and significant relationship of employee productivity with all four independent variables. The wages had the highest $r$ value (0.829), it means when the wages increase the workers productivity also increase. Moreover, benefit $(r=0.775)$ and positive climate $(r=0.721)$ were also depicts highly positive correlated to employee productivity. Only appreciation had a moderate $r$ value $(0.564)$ Findings provided enough evidence to suggest that there was a relationship between these constructs and employee productivity. It can be documented that employee productivity increases in presence of these four elements.

Coefficient of Determination

Table 4: Model of summary

\begin{tabular}{ccccc}
\hline Model & $\mathbf{R}$ & $\mathbf{R}^{\mathbf{2}}$ & Adjusted $\mathbf{R}^{\mathbf{2}}$ & Std. Error of the Estimation \\
\hline 1 & 0.681 & 0.529 & 0.47 & 0.899
\end{tabular}

$\mathrm{R}^{2}$ value is said to be strong when in explaining the variation of the independent variables on the dependent variable the value is between 0 (zero) and 1 (one). According to Table 4, the Coefficient of determination $\left(R^{2}\right)$ was 0.529 ; meaning that all the 4 variables can explain its effect on employee 
INTERNATIONAL JOURNAL OF ACADEMIC RESEARCH IN BUSINESS AND SOCIAL SCIENCES Vol. 10, No. 4, April, 2020, E-ISSN: 2222-6990 @ 2020 HRMARS

productivity in Oil Palm Estate Selandar Jasin Melaka equal to 52.9\%. The remaining $47.1 \%$ was influenced by other factors that are not investigated, or out of this research model. These findings are consistent with the predicted relationships and provide support to our conceptual model.

Multiple Linear Regressions Analysis

Table 5: Results of multiple regression analysis

\begin{tabular}{lccccc}
\hline & \multicolumn{3}{c}{ Unstandardized coefficients } & \multicolumn{3}{c}{ Standardized coefficients } \\
Model & B & Standard error & $\beta$ & $T$ & significance \\
\hline Appreciation & 0.197 & 0.463 & 0.0 & 0.464 & 0.006 \\
Benefit & 0.359 & 0.128 & 0.426 & 2.809 & 0.002 \\
Wages & 0.393 & 0.111 & 0.342 & 2.907 & 0.000 \\
Positive climate & 0.205 & 0.114 & 0.232 & 1.764 & 0.007
\end{tabular}

Next, multiple regression analysis was applied to see which factor impact employee productivity. Regression analysis aids in order to measure the relative strength of independent variable on dependent variable. All direct positive relationship between variables and job satisfaction were examined using multiple regression analysis to ascertain the extent to which they explain that the variance in job satisfaction. Model 1 serves as the base model incorporating all core independent variables: wages, benefit, positive climate and appreciation.

All four variables significantly impact job satisfaction with wages $(B=0.528)$ providing the largest level of impact, followed by benefits $(B=0.359)$, positive climate $(B=0.205)$ and then appreciation $(B=0.197)$. This indicate that if the rate of each factor increases, then employee productivity of Oil Palm Estate Selandar Jasin Melaka will also increase.

\section{Conclusion}

Labour productivity in oil palm estate Selandar Jasin Melaka still below the par based from the national target. Findings from the study enabled the researcher to identify the major strategies that can be used to raise the bar for labour productivity. The investigation into the origins of these deficiencies and assessment of their effect could assist in solving the problem. Moreover, the wages of the major factors contributing to the shortfalls gives the oil palm industry impetus to direct its attention. In addition to the geographic limitations of the study, we also recognise that limiting our focus to the field sites rather than full oil palm headquarters companies may have led to bias in our results. A valuable extension would be to perform a full 360 study of oil palm companies to appreciate the link between the back office and the site management.

Despite the above limitations, we believe that this study provides a contribution to the literature. In addition, the results of the study will provide a better understand the concept of employee's productivity. The findings reported here can be used by the estate managers to be more particular to all these factors especially salary. Wages or salaries must be competitive as compared with other economic sector and commensurate with the nature of plantation work, which is quite heavy, difficult, dangerous and challenging. In the current situation, wage of RM1,100 is no longer appropriate. Considering the cost of living is rising every day, the rate of wages can be categorized as very low especially for the local workers. Method of daily wages which is normally implemented in 
INTERNATIONAL JOURNAL OF ACADEMIC RESEARCH IN BUSINESS AND SOCIAL SCIENCES Vol. 10, No. 4, April, 2020, E-ISSN: 2222-6990 @ 2020 HRMARS

the oil palm plantation resulted in low income compared to the manufacturing industry. At present, the government has already implemented and emphasized the minimum monthly wages method, but it is still not competitive with manufacturing sector and has become the second riddle to local. Therefore, adequate and prompt remuneration in addition to appraisal systems embracing quality, schedule milestones and commensurate rewards must be used.

Moreover, overtime work is the common means of schedule acceleration especially during peak season from July until November. In positive climate facet, management should provide a safe and productive environment, provision of amenities such as personal protective equipment (PPE), modern tools, restroom and canteen facilities to lift morale. The manager also should provide transport especially to the workers especially to the harvester. In addition, the study found that the appreciation (reward) was statistically significant and positively related to overall employee productivity. The employees feel happy and being honor when the manager give them a sack of rice, a $1 \mathrm{~kg}$ Milo, $4 \mathrm{~kg}$ of cooking oil and other necessitySuch a study would allow us to determine if some of the issues we observed were a function of HRM practices or a function of the communication of HRM decisions between the field and the back office. This sector must be transformed through several improvements.

\section{References}

Ahmad, T., Farrukh, T., Nazir, S. (2015), Capacity building boost employee's performance. Industrial and Commercial Training, Vol. 47 No. 2, 61-66.

Ahmad, S., Ali, I., Rehman, K., Khan, M. A., and Waseemullah. (2010), Insecure job and low pay leads to job dissatisfaction, Interdisciplinary Journal of Contemporary Research in Business, vol. 1, No. 11, 222-263.

Al Hawari, M. (2008), Arab Industrial Sector and the Prospects for Development and Operation. A Working Paper Submitted to the Conference of the Arab Forum for Development and Operating Primarily in the 15-16 November. Cairo: Arab Labour Organization, 1-7.

Aliuddin, M. A. B., Nurfirdaus, A. R., Syahrizan, S. (2018), Comparison of an effective working hour and harvesting cost between manual harvesting (chisel and sickle) and mechanised harvesting (CKAT and motorised cutter) in oil palm plantation. International Journal of Engineering \& Technology, Vol. 7 No.2.29, 282-286.

Andy, F. (2017), Discovering Statistics Using IBM SPSS Statistics. Published by SAGE Publications Ltd.

Audry, T. (2013), Improving worker satisfaction yields improved worker - retention rates. Employment Relations. Vol. 39 No.4, 27-31

Arslan, M. (2018) Organizational cynicism and employee performance. Journal Globe Responsible. 415-431. doi:10.1108/jgr-05-2018-0014

Bozeman, B., and Gaughan, M. (2011), "Job satisfaction among university faculty: individual, work, and institutional determinants", Journal of Higher Education, Vol. 82 No. 2, 154-186

Cho, S., Woods, R. H., and Jang, S. (2006), "Measuring the impact of HRM Practices on hospitality firms' performance, Hospitality Management, Vol. 22, 262-277.

Coakes, S. J., and Steed, L.G. (2007), SPSS: Analysis without anguish: Version 14.0 for windows, John Wiley \& Sons, Australia.

Farahida, Z., Syahrizan, S., Aziz, M. F. A. (2018), Negatives Impact Faced by Oil Palm Estate Management in managing Foreign Workers: A Case Study. International Journal Academic 
INTERNATIONAL JOURNAL OF ACADEMIC RESEARCH IN BUSINESS AND SOCIAL SCIENCES Vol. 10, No. 4, April, 2020, E-ISSN: 2222-6990 C 2020 HRMARS

Research Business Social Science. Vol. 8 No. 9, 1525-1531.

Green, S., Lissitz, R., and Mulaik, S. (1977), Limitations of coefficient alpha as an index of test unidimensional. Educational Psychological Measurement. Vol. 37, 827-38.

Hameed, A., and Amjad, S. (2009), Impact of Office Design on Employees' productivity: A Case Study of Banking Organizations of Abbottabad, Pakistan. Journal Public Affairs Administration and Management. Vol. 3 No. 1, 1-13

Harmon, P. (2007), Business process change, (2nd ED): A guide for business managers and BPM and Six Sigma professionals. Business Process Trends, The MK/OMG Press.

Hermsen, J., and Rosser, V. (2008), Examining work engagement and job satisfaction of staff members in higher education, CUPA-HR Journal, Vol. 59 No. 2, 10-18.

Hinkle, D. E., Wiersma, W., and Jurs, S. G. (2003), Rule of Thumb for Interpreting the Size of a Correlation Coefficient Matrix Showing Correlation Coefficients Appropriate for Scales of Measurement for Variable X and Variable Y. Applied Statistics for the Behavioural Science. $5^{\text {th }}$ Edition, Boston: Houghton Mifflin.

Hoskins, D. (2006). The Workplace in an Age of New "Markets Workforce New Responsibility. The Gensler Design + Performance Index The U.S Workplace Survey. Retrieved from http://www.gensler.com/uploads/documents/USWorkplaceSurvey

LaBelle, J. E. (2005), The paradox of safety hopes and rewards: Are you rewarding the right behaviour, Professional Safety. 37-39.

Mohammad, A. A., Norehan, A., and Jamal, A. (2014), Repulsion and attraction factors among local labor force in oil palm plantation, International journal of Science Commerce and Humanities, Vol. 2 No. 2, 59-69.

MPOB. (2018), Yield statistic for smallholder in Malaysia. Retrieved from https://www.mpob.org.my

MPOB. (2019), Oil Palm estate labour statistic in Malaysia. Retrieved from https://www.mpob.org.my

MPOCC. (2019), Oil palm area certified Malaysia. Retrieved from https://www.mpocc.org.my/certified-areas.

O'Reilly, C. A., and Chatman. (1986), The effects of compliance, identification, and internalization on prosocial behaviour, Journal of Applied Psychology. Pp. 492- 499.

Pawirosumarto, S., Sarjana, P. K., and Muchtar, M. (2017), Factors affecting employee performance of PT.Kiyokuni Indonesia, International Journal Law Management. Vol. 59 No. 4, 602-614.

Schaufeli, W. B., Saianova, M., and Gonzales, R. V. (2002), The measurement of engagement and burnout: a two samples confirmatory factor analytic approach. Journal of Happiness Studies. Vol. 3 No. 1, 71-92.

Shuja, I., Guohao, L., and Akhtar, S. (2017), Effects of job organizational culture , benefits, salary on job satisfaction ultimately affecting employee retention, Review of Public Administration Management.doi. 10.4172/2315-7844.1000229.

Syahrizan, S., Zulkefli, F., Khairuddin, M. N., Zaini, M. R., Bakar, M. A., Sani, S., and Rakibe, I. (2017), Buffalo Assistance for In-Field Collection of Fresh Fruit Bunches in Oil Palm Plantation. The 2nd International Symposium on Sustainable Agriculture and Agro-Industry (ISSAA2017), At Walailak University Thailand.

Teddie, C., and Tashakkori, A. (2008), Foundations of mixed methods research. Sage Publications, Thousand Oaks pp. 173-174. 
INTERNATIONAL JOURNAL OF ACADEMIC RESEARCH IN BUSINESS AND SOCIAL SCIENCES

Vol. 10, No. 4, April, 2020, E-ISSN: 2222-6990 @ 2020 HRMARS

Ting Y., (1997), Determinants of job satisfaction of federal government employees. Public Person Manage Vol. 26, 313-334.

Wong, O. M. A., Dean, A. M., and White, C. J. (1999), Analysing service quality in the hospitality industry, Managing Service Quality, Vol. 9 No. 2, 136-143.

Wei, Q., and Rowley, C., (2009), Pay for performance in China's non-public sector enterprises. AsiaPacific J Bus Adm. 2009;1(2):119-143. doi:10.1108/17574320910989087

Yusof, N. M., Syahrizan, S., Zulkefli, F., and Bakar, M. A. (2017), Factors influencing the Cocoa Smallholders Behaviour Decision Making in Hilir Perak, International Journal Academic Research Business Social Science, Vol. 7 No. 10, 637- 643. 